\title{
Characterization of the pyrethroid resistance profile of Rhipicephalus (Boophilus) microplus populations from the states of Rio Grande do Sul and Mato Grosso do Sul, Brazil
}

\author{
Caracterização do perfil de resistência do Rhipicephalus (Boophilus) microplus a piretróides \\ em populaçóes dos estados do Rio Grande do Sul e Mato Grosso do Sul, Brasil \\ Márcia Cristina Mendes ${ }^{1 *}$; Fernanda Calvo Duarte ${ }^{1}$; João Ricardo Martins²; Guilherme Marcondes Klafke²; \\ Leonardo Costa Fiorini' ${ }^{1}$; Antônio Thadeu Medeiros de Barros ${ }^{3}$
}

${ }^{1}$ Instituto Biológico, São Paulo, SP, Brasil

${ }^{2}$ Laboratório de Parasitologia, Instituto de Pesquisas Veterinárias "Desidério Finamor", Fundação Estadual de Pesquisa Agropecuária - Fepagro, Eldorado do Sul, RS, Brasil

${ }^{3}$ Empresa Brasileira de Pesquisa Agropecuária - Embrapa Pantanal, Corumbá, MS, Brasil

Received March 14, 2013

Accepted May 14, 2013

\begin{abstract}
Cattle ticks Rhipicephalus (Boophilus) microplus are mainly controlled in Brazil by means of acaricide products, without any official policies in this regard. Acaricides continue to be sold indiscriminately, and this has contributed towards making the problem of resistance widespread, thus making diagnosis and monitoring of tick resistance essential. Here, bioassays (larval packet test) were performed on tick populations from the states of Rio Grande do Sul and Mato Grosso do Sul regarding their susceptibility to cypermethrin, deltamethrin and flumethrin. All the tick samples tested showed resistance to cypermethrin (10) (resistance factor (RF) ranging from 5.6 to 80.3) and deltamethrin (10) (RF ranging from 2.4 to 83.1). Six out of eight populations were resistant to flumethrin (RF ranging from 3.8 to 8.2). PCR molecular analyses did not show any T2134A mutations in the voltage-gated sodium channel gene, in any of the sampled populations. The results from this study highlight the critical status of resistance of the cattle tick to synthetic pyrethroids in the regions studied. Further studies are needed to identify the mechanisms responsible for the resistant phenotypes observed in the bioassays. This was the first detection of flumethrin resistance in Brazil.
\end{abstract}

Keywords: Cattle tick, acaricide resistance, synthetic pyrethroids, PCR.

\section{Resumo}

O controle do carrapato Rhipicephalus (Boophilus) microplus no Brasil é feito principalmente com produtos acaricidas, sem uma política de controle oficial. A venda destes produtos continua ocorrendo de maneira indiscriminada, o que tem contribuído para generalizar o problema da resistência em todo o país, tornando essencial seu diagnóstico e monitoramento. Bioensaios (teste do pacote de larvas) foram conduzidos com populaçóes de carrapatos do Rio Grande do Sul e Mato Grosso do Sul, com relação à sua suscetibilidade a três princípios ativos piretróides. Todas as amostras analisadas mostraram resistência à cipermetrina (10), com fatores de resistência (FR) de 5,6 a 80,3, e à deltametrina, com FR variando de 2,4 a 83,1. Seis das oito amostras foram resistentes à flumetrina (FR de 3,8 a 8,2). Análises moleculares utilizando PCR demonstraram que em todas as populações amostradas não foram encontrados alelos com a mutaçáo T2134A no gene do canal de sódio controlado por voltagem. Os resultados deste estudo evidenciam a situaçáo crítica da resistência do carrapato bovino ao grupo dos piretróides sintéticos nas regiōes estudadas. Novos estudos são necessários para identificar os mecanismos responsáveis pelos fenótipos resistentes observados nos bioensaios. Este é o primeiro relato da resistência a flumetrina no Brasil.

Palavras-chave: Carrapatos-dos-bovinos, resistência acaricida, piretróides sintéticos, PCR.

\footnotetext{
${ }^{*}$ Corresponding author: Márcia Cristina Mendes

Instituto Biológico, CEP 04014-002, São Paulo, SP, Brasil

e-mail: mendes@biologico.sp.gov.br
} 


\section{Introduction}

Animal health standards and requirements are at the center of current national and international debates because of everincreasing consumer consciousness regarding the risks associated with consumption of livestock-derived products. In addition, producers are also faced with concerns regarding environmentally responsible sustainable development.

Controlling cattle ticks Rhipicephalus (Boophilus) microplus is an important challenge for Brazilian cattle producers, given their widespread distribution and the economic losses involved in acquisition and application of acaricides with the aim of reducing tick infection. Furthermore, pesticide residues tend to increase in animal-derived products, since resistant ticks require acaricide applications at higher concentrations and increased frequency. Acaricide resistance is a consequence of frequent selection of resistant individuals in tick populations in fields, after repetitive use of a single acaricide chemical class for long periods (CONWAY; COMINS, 1979).

Unfortunately, there is no official policy for cattle tick control in Brazil. Moreover, acaricides are frequently used irrationally, with few if any technical criteria for choosing the most appropriate product. Cattle tick control depends on acaricide efficiency in order to overcome the existing resistance to different classes of acaricides and on delaying the development of resistance towards new chemical classes, with adoption of rational acaricide application methods.

One of the most recommended strategies for avoiding resistance is to alternate the chemical acaricide groups used for controlling cattle tick populations (SUTHERST; COMINS, 1979). This strategy needs to be based on studying the acaricide resistance profile of the tick population of the location in question (i.e. the region or farm).

In Brazil, the most used synthetic pyrethroid insecticides are cypermethrin and deltamethrin. Over recent years, use of cypermethrin in association with organophosphates (OP) has increased with the aim of achieving better control.

Synthetic pyrethroid resistance was studied by Nolan et al. (1989) and Nolan (1990) in Australia. These authors characterized the resistance in three tick strains: Marmor (resistant to deltamethrin and cypermethrin, in the absence of flumethrin), Lamington (resistant to deltamethrin and cypermethrin, but susceptible to flumethrin) and Parkhurst (resistant to flumethrin, deltamethrin and cypermethrin).

In Brazil, synthetic pyrethroid resistance has been reported since 1980 in the states of Rio de Janeiro (LEITE, 1988), Rio Grande do Sul (FARIAS et al., 2008), Goiás (FERNANDES, 2001), Paraná (SOUZA et al., 2003), Bahia (CAMPOS Jr.; OLIVEIRA, 2005), Minas Gerais (FURLONG et al., 2007), São Paulo (MENDES et al., 2007) and Mato Grosso do Sul (GOMES et al., 2011).

Synthetic pyrethroids exert their acaricide effect in neuronal voltage-gated sodium channels, and mutations in these protein coding sequences can determine structural changes leading to reduced synthetic pyrethroid interaction, thus limiting their acaricide effect (SODERLUND; KNIPPLE, 2003).
Insensitivity of the active site, as determined by a point mutation (Phe replaced by Ile; T2134A) in the conserved IIIS6 segment of the sodium channel of the San Felipe Mexican strain of $R$. (B.) microplus (which is highly resistant to DDT and permethrin), was identified by He et al. (1999). This mutation has also been found in many studies developed in Mexico (ROSARIO-CRUZ et al., 2005; 2009). In Brazil, however, this mutation was not found in resistant ticks from the states of Mato Grosso do Sul (ANDREOTTI et al., 2011), Minas Gerais (DOMINGUES et al., 2012), São Paulo, Espirito Santo, Paraná and Rio Grande do Sul (LOVIS et al., 2012). Jonsson et al. (2010) reported the mutation G214T in the domain II S4-S5, which is a glycine-to-valine change associated with resistance to the pyrethroid flumethrin.

The objectives of the present work were to diagnose synthetic pyrethroid resistance using standardized bioassays and to investigate occurrences of the T2134A mutation in field populations of $R$. (B.) microplus in the states of Rio Grande do Sul and Mato Grosso do Sul.

\section{Materials and Methods}

\section{Ticks}

\section{Susceptible strain}

The Mozo strain provided by the Department of Parasitology, "Miguel C. Rubino” Veterinary Laboratories Division, (DiLaVe), Ministry of Livestock, Agriculture and Fisheries (MGAP), Uruguay, was used as a reference susceptible strain in the diagnostic bioassays.

This strain was maintained in heifers at the Biological Institute of São Paulo. The animal handling was conducted in accordance with the certification granted by the Ethics Committee for Animal Experimentation of the Biological Institute (protocol number 24/06 CETEA-IB).

\section{R. (B.) microplus field populations}

Tick samples were collected in the years 2010 and 2011, from farms located in the states of Mato Grosso do Sul $(n=4)$ and Rio Grande do Sul $(n=6)$. Table 1 lists the tick populations analyzed, their respective origins and the previous acaricide treatments.

\section{Tick preparation}

The experiments were carried out following the FAO guidelines (2004) for the larval packet test. On each farm, engorged females (at least $4 \mathrm{~mm}$ each) were collected from at least 10 animals and taken to the laboratory at the Biological Institute of São Paulo. After being washed in water and dried on paper towels, these females were placed in a petri dish for egg laying. The containers were given identification and kept in an incubator at $27 \pm 1{ }^{\circ} \mathrm{C}$ and relative humidity of $80 \pm 5 \%$ for 14 days. The eggs were 
Table 1. Assignment of $R$. (B.) microplus populations analyzed and corresponding previous use of acaricides.

\begin{tabular}{|c|c|c|c|}
\hline State & Strains (symbol) & Production purpose & Acaricides used (active components) \\
\hline \multirow[t]{4}{*}{ Mato Grosso do Sul } & Canga (CG) & milk & deltamethrin; cypermethrin; fipronil and ivermectin \\
\hline & Bonfim (BF) & milk & chlorpyrifos + cypermethrin in association \\
\hline & Galheiro $(\mathrm{GH})$ & meat & cypermethrin; cypermethrin + ethion in association \\
\hline & Antônio (AT) & meat & cypermethrin; cypermethrin + ethion in association; amitraz \\
\hline \multirow[t]{6}{*}{ Rio Grande do Sul } & Checo (CE) & - & - \\
\hline & Pântano (PA) & meat & amitraz; fipronil; organophosphate; pyrethroid \\
\hline & Gabriel (GB) & meat & macrocyclic lactones; amitraz; cypermethrin; chlorpyrifos \\
\hline & Lousada (LS) & meat & fipronil; amitraz; cypermethrin; chlorpyrifos \\
\hline & Cavalcanti (CT) & meat & fluazuron; ivermectin; cypermethrin; chlorpyrifos \\
\hline & Cachoeira (CR) & meat & - \\
\hline
\end{tabular}

incubated in sealed glass vials, closed with wet cotton. The larvae used in the bioassays were between 14 and 21 days old.

\section{Larval Packet Test (LPT)}

The LPT was performed as prescribed by FAO (2004) with some minor modifications. The synthetic pyrethroids were used at their technical grades: cypermethrin (93.59\% purity; Allvet), deltamethrin (99.2\% purity; Coopers Animal Health) and flumethrin (97\% purity; Sigma-Aldrich). The acaricides were dissolved in a vehicle composed of two parts of trichloroethylene and one part of olive oil. For each active ingredient, a dilution series was set up in order to obtain a concentration gradient resulting in 0 to $100 \%$ larval mortality.

The concentrations used were: flumethrin $-0.0079922 \%$; $0.0133204 \%$; $0.02202008 \% ; 0.0275251 \%$; $0.0344064 \%$; $0.043008 \% ; 0.05376 \% ; 0.0672 \% ; 0.084 \%$ and $0.12 \%$; cypermethrin $-0.1269034 \% ; 0.2115072 \% ; 0.58752 \% ; 0.9792 \%$; $1.632 \%$ and $4 \%$; and deltamethrin $-0.085 \% ; 0.107 \% ; 0.134 \%$; $0.167 \%$; $0.209 \%$; 0.262\%; 0.327\%; 0.409\%; 0.512\%; $0.64 \%$ and $0.8 \%$. For each dilution series, a negative control was used (composed only of the vehicle). For each concentration, three repetitions were made. A volume of $670 \mu \mathrm{L}$ of each solution was applied to Whatman No. $1(7.5 \times 8.5 \mathrm{~cm})$ filter paper.

After saturation, these paper filters were left for 24 hours at room temperature for trichloroethylene evaporation. Approximately 100 larvae were transferred to each packet using a paintbrush, and the packet was closed with paper clips and kept in an incubator $\left(27 \pm 1{ }^{\circ} \mathrm{C}\right.$ and $80 \% \pm 5 \%$ relative humidity). After 24 hours, the packets were opened, and both the live and the dead larvae were counted, with the help of a vacuum pump and a manual counter. The ability of the larvae to walk on the surface of the filter paper was used as the criterion for determining whether larvae were dead or alive.

\section{Data analysis}

The percentage mortality for each concentration was calculated as the number of dead larvae relative to the total number of larvae.
The data obtained from the tests were submitted to statistical analysis by means of the Polo Plus software (LeOra Software, 2004).

These analyses provided the $\mathrm{LC}_{50}$ and $\mathrm{LC}_{99}$ for each population (lethal concentrations for $50 \%$ and $99 \%$ of the population, respectively) with $95 \%$ confidence intervals, along with the slopes of the regression lines. The resistance factor (RF) of each population studied was calculated by dividing the $\mathrm{LC}_{50}$ of the field population by the mean $\mathrm{LC}_{50}$ of the assays performed with the susceptible reference strain (Mozo).

\section{DNA extraction}

Thirty larvae from each population were subjected to DNA extraction as described by Guerrero et al. (2001). Briefly, larvae were place individually in $1.5 \mathrm{~mL}$ microcentrifuge tubes containing $20 \mathrm{mM}$ Tris- $\mathrm{HCl}$ (pH 8.4) and $50 \mathrm{mM} \mathrm{KCl} 50$ (Invitrogen). The larvae were crushed using a round-pointed pestle, and the resulting suspension was heated to $100{ }^{\circ} \mathrm{C}$ for 3 minutes, and used directly in the PCRs, or was frozen at $-20{ }^{\circ} \mathrm{C}$ until use.

\section{Polymerase chain reaction}

To detect the mutation T2134A, the protocol developed by Guerrero et al. (2001) was used. In each reaction, reagents were distributed at the following concentrations: PCR buffer of $20 \mathrm{mM}$ Tris- $\mathrm{HCl}(\mathrm{pH} 8.4)$ and $50 \mathrm{mM} \mathrm{KCl}$ (Invitrogen), dNTPs (0.2 mM each), $\mathrm{MgCl}_{2}(2 \mathrm{mM})$, Dream Taq DNA Polymerase $^{\circledast}(1 \mu \mathrm{L})$ (Fermentas), along with $2.5 \mu \mathrm{L}$ of the larva suspension. To amplify susceptible alleles, the following primers were used: FG221 (5'-TTATCTTGGCTCCTTCT-3') and FG227 (5'-TTGTTCATTGAAATTGTCGA-3'). To amplify resistant alleles, the following primers were used: FG222 (5'-TTATCTTCGGCTCCTTCA-3') and FG227 (5'-TTGTTCATTGAAATTGTCGA-3'). Each of these was used at a concentration of $0.4 \mu \mathrm{M}$.

The conditions programmed in the TC-02024 Multigene ${ }^{\mathrm{TM}}$ mini thermal cycler $\left(\right.$ Labnet International $\left.{ }^{\oplus}\right)$ that was used to amplify the gene fragments were as follows: $94^{\circ} \mathrm{C}$ for $5 \mathrm{~min}, 40$ cycles of $94^{\circ} \mathrm{C}$ for $45 \mathrm{sec}, 60^{\circ} \mathrm{C}$ for $30 \mathrm{sec}$ and $72{ }^{\circ} \mathrm{C}$ for $40 \mathrm{sec}$, 
with a final step of $72{ }^{\circ} \mathrm{C}$ for $7 \mathrm{~min}$. The amplified fragments were subjected to electrophoresis on 3\% agarose gel stained with Sybr Safe Gel Stain ${ }^{\text {тM }}$ (Life Technologies ${ }^{\circledR}$ ), and were analyzed on a UV transilluminator.

Susceptible and resistant-allele controls were included through addition of a sample containing larval genomic DNA from the Mexican strain San Felipe (heterozygous for the T2134A mutation).

\section{Results}

All of the tick samples analyzed showed resistance to cypermethrin (Table 2). The RFs ranged from 5.6 to 80.3 in Rio Grande do Sul and from 8.8 to 28.3 in Mato Grosso do Sul.

As observed for cypermethrin, all of the tick populations analyzed were resistant to deltamethrin (Table 3), with RFs from 2.4 to 83.1 in Rio Grande do Sul and from 18.7 to 47.9 in Mato Grosso do Sul. The slope values were all below 3.2.

Six of the eight populations on which flumethrin had been used (Table 4) showed resistance, with RFs from 3.8 to 8.2. Two populations were susceptible to flumethrin: one from the state of Mato Grosso do Sul $(\mathrm{RF}=0.4)$ and the other from Rio Grande do Sul $(\mathrm{RF}=1.4)$. In the Mato Grosso do Sul samples, the lowest RF found was 5.6 and the highest, 8.2. In the state of Rio Grande do Sul, the RF for flumethrin ranged from 6.4 to 7.2.

The PCR results showed that none of the 10 populations analyzed possessed the mutant allele T2134A.

\section{Discussion}

Today in Brazil, commercial acaricides containing flumethrin as the active compound are no longer available, in spite of its past widespread use in the 1980s and 1990s in association with the organophosphate coumaphos. This may account for the lower RFs calculated for flumethrin (3.8 to 8.2), in comparison with those calculated for cypermethrin (5.6 to 80.3) and deltamethrin (2.4 to 83.1) (Tables 2, 3 and 4).

Since flumethrin-based acaricides had not been used for over a decade, one important aspect of the present study was to detect lateral resistance among the synthetic pyrethroids analyzed. Seven of the eight populations that had been exposed to flumethrin showed resistance towards this compound. In Australia, Nolan et al. (1989) described three strains with different patterns of resistance

Table 2. $R$. (B.) microplus susceptibility to cypermethrin (larval packet test) in samples from the states of Mato Grosso do Sul and Rio Grande do Sul.

\begin{tabular}{|c|c|c|c|c|c|c|}
\hline State & Strain & $\mathbf{n}$ & Slope (SD) & $\mathrm{LC}_{50}(95 \% \mathrm{CI})$ & $\mathrm{LC}_{99}(95 \% \mathrm{CI})$ & $\mathrm{RF}_{50}$ \\
\hline- & Mozo & 13353 & $4.132(0.068)$ & $0.0147(0.0140 .0155)$ & $0.1374(0.1153-0.1691)$ & \\
\hline MS & CG & 1091 & $1.86(0.107)$ & $0.346(0.308-0.386)$ & $6.159(4.648-8.723)$ & 23.5 \\
\hline MS & $\mathrm{BF}$ & 1096 & $2.248(0.138)$ & $0.2(0.172-0.228)$ & $2.171(1.688-3.001)$ & 13.6 \\
\hline MS & $\mathrm{GH}$ & 995 & $1.764(0.138)$ & $0.13(0.105-0.154)$ & $2.712(1.971-4.149)$ & 8.8 \\
\hline MS & AT & 971 & $2.024(0.114)$ & $0.417(0.33-0.519)$ & $5.876(3.534-12.874)$ & 28.3 \\
\hline RS & $\mathrm{CE}$ & 2185 & $3.229(0.159)$ & $1.18(1.098-1.266)$ & $6.197(5.308-7.455)$ & 80.3 \\
\hline RS & PA & 1509 & $3.155(0.134)$ & $0.467(0.433-0.504)$ & $2.552(2.173-3.092)$ & 31.8 \\
\hline RS & GB & 2555 & $2.446(0.078)$ & $0.683(0.615-0.755)$ & $6.101(4.855-8.078)$ & 46.5 \\
\hline RS & LS & 491 & $2.088(0.288)$ & $0.09(0.057-0.12)$ & $1.17(0.807-2.157)$ & 6.1 \\
\hline RS & CT & 1946 & $2.648(0.109)$ & $0.48(0.407-0.557)$ & 3.627 (2.719-5.367) & 32.6 \\
\hline RS & CR & 1899 & $1.891(0.156)$ & $0.082(0.049-0.111)$ & $1.395(0.9341-2.801)$ & 5.6 \\
\hline
\end{tabular}

MS: Mato Grosso do Sul; RS: Rio Grande do Sul; n: number of larvae; SD: standard deviation; LC: lethal concentration; $95 \%$ CI: $95 \%$ confidence interval; $\mathrm{RF}$ : resistance factor.

Table 3. $R$. (B.) microplus susceptibility to deltamethrin (larval packet test) in samples from the states of Mato Grosso do Sul and Rio Grande do Sul.

\begin{tabular}{|c|c|c|c|c|c|c|}
\hline State & Population & $\mathbf{n}$ & Slope (SD) & $\mathrm{LC}_{50}(95 \% \mathrm{CI})$ & $\mathrm{LC}_{99}(95 \% \mathrm{CI})$ & $\mathbf{R F}_{50}$ \\
\hline & Mozo & 2349 & $2.61(0.095)$ & $0.00373(0.0028-0.005)$ & $0.02902(0.015-0.095)$ & \\
\hline MS & CG & 2141 & $1.531(0.115)$ & $0.07(0.058-0.084)$ & $2.365(1.708-3.65)$ & 18.7 \\
\hline MS & $\mathrm{BF}$ & 1828 & $2.838(0.191)$ & $0.084(0.075-0.093)$ & $0.555(0.475-0.679)$ & 22.5 \\
\hline MS & $\mathrm{GH}$ & 1959 & $2.93(0.163)$ & $0.104(0.096-0.112)$ & $0.65(0.563-0.774)$ & 27.8 \\
\hline MS & AT & 1965 & $3.114(0.136)$ & $0.179(0.169-0.188)$ & $0.998(0.879-1.158)$ & 47.9 \\
\hline RS & $\mathrm{CE}$ & 1660 & $2.585(0.156)$ & $0.31(0.265-0.366)$ & $2.458(1.65-4.407)$ & 83.1 \\
\hline RS & PA & 2567 & $3.114(0.111)$ & $0.2(0.191-0.208)$ & $1.115(0.996-1.27)$ & 53.6 \\
\hline RS & GB & 2872 & $3.001(0.109)$ & $0.197(0.189-0.205)$ & $1.172(1.04-1.343)$ & 52.8 \\
\hline RS & LS & 566 & $2.744(0.331)$ & $0.07(0.053-0.084)$ & $0.491(0.382-0.725)$ & 18.7 \\
\hline RS & CT & 2103 & $3.075(0.142)$ & $0.127(0.112-0.14)$ & $0.723(0.595-0.937)$ & 34 \\
\hline RS & CR & 1591 & $1.588(0.115)$ & $0.009(0.004-0.014)$ & $0.261(0.115-2.007)$ & 2.4 \\
\hline
\end{tabular}

MS: Mato Grosso do Sul; RS: Rio Grande do Sul; n: number of larvae; SD: standard deviation; LC: lethal concentration; $95 \%$ CI: $95 \%$ confidence interval; RF: resistance factor. 
Table 4. $R$. (B.) microplus susceptibility to flumethrin (larval packet test) in samples from the states of Mato Grosso do Sul and Rio Grande do Sul.

\begin{tabular}{|c|c|c|c|c|c|c|}
\hline State & Population & n & Slope (SD) & $\mathrm{LC}_{50}(95 \% \mathrm{CI})$ & $\mathrm{LC}_{99}(95 \% \mathrm{CI})$ & $\mathbf{R F}_{50}$ \\
\hline & Mozo & 2099 & $1.073(0.095)$ & $0.005(0.002-0.007)$ & $0.674(0.34-2.129)$ & - \\
\hline MS & CG & 1881 & $2.311(0.112)$ & $0.028(0.025-0.03)$ & $0.281(0.212-0.407)$ & 5.6 \\
\hline MS & $\mathrm{BF}$ & 2222 & $3.121(0.129)$ & $0.019(0.018-0.021)$ & $0.107(0.089-0.135)$ & 3.8 \\
\hline MS & $\mathrm{GH}$ & 1786 & $1.098(0.133)$ & $0.002(0-0.005)$ & $0.259(0.118-2.017)$ & 0.4 \\
\hline MS & AT & 1800 & $2.593(0.119)$ & $0.041(0.037-0.045)$ & $0.32(0.239-0.474)$ & 8.2 \\
\hline RS & PA & 1465 & $2.697(0.147)$ & $0.034(0.031-0.038)$ & $0.251(0.183-0.393)$ & 6.8 \\
\hline RS & GB & 1408 & $2.696(0.148)$ & $0.036(0.032-0.04)$ & $0.26(0.186-0.424)$ & 7.2 \\
\hline RS & LS & 548 & $1.953(0.228)$ & $0.007(0.005-0.01)$ & $0.114(0.082-0.187)$ & 1.4 \\
\hline RS & CT & 2161 & $2.975(0.15)$ & $0.032(0.028-0.036)$ & $0.192(0.0141-0.307)$ & 6.4 \\
\hline
\end{tabular}

MS: Mato Grosso do Sul; RS: Rio Grande do Sul; n: number of larvae; SD: standard deviation; LC lethal concentration; $95 \%$ CI: 95\% confidence interval; RF: resistance factor.

to synthetic pyrethroids: Parkhurst strain, resistant to flumethrin, deltamethrin and cypermethrin; Marmor strain, resistant to deltamethrin and cypermethrin but susceptible to flumethrin; and Lamington strain, resistant to flumethrin but susceptible to cypermethrin. Therefore, the resistance pattern found in the populations assessed in the present study correspond to the Parkhurst strain. Regarding flumethrin, the $\mathrm{GH}$ population from Mato Grosso do Sul presented $\mathrm{LC}_{50}(0.002 \%)$ that was very close to the $\mathrm{LC}_{50}$ of the Yeerongpilly strain $(0.0026 \%)$

All of the populations from the state of Mato Grosso do Sul had previously been exposed to cypermethrin. Only the CG population had previously been exposed to both deltamethrin and cypermethrin. This information may account for the tick resistance to synthetic pyrethroids in all of the populations analyzed, which confirms the previous results of Gomes et al. (2011) in this state, who found cypermethrin efficacy towards $R$. (B.) microplus adults of only $19.94 \%$.

The data from the present study emphasize the high frequency of resistance observed in the state of Rio Grande do Sul. According to Jonsson et al. (2007), the larval packet test (LPT) provides better precision of information about the resistance.

There is a consensus that resistance among cattle ticks to synthetic pyrethroids is currently widespread in Brazil, and therefore that synthetic pyrethroid-based formulations must be used with caution and only in absence of resistance.

The PCR results obtained were in agreement with those found by Andreotti et al. (2011), Domingues et al. (2012) and Lovis et al. (2012), which demonstrated absence of the point mutation (T2134A) conferring SP resistance. Morgan et al. (2009) found another non-synonymous point mutation (L64I) in $R$. (B) microplus populations resistant to SP in Australia. Thus, it is plausible that another mutation is also associated with resistance to synthetic pyrethroids in Brazil.

Use of molecular diagnostic tools might provide valuable information for cattle tick management and control in the field, since these make it possible to monitor the frequencies of resistant alleles in order to forecast accumulations of resistant or susceptible allele over defined periods of time.

Prior susceptibility evaluation on the tick population is essential, in order to adjust the acaricide use to the specific characteristics of each farm. In this manner, better acaricide efficiency can be achieved, with the aim of reducing selection pressure to be as weak as possible. In order to follow all of these criteria, field education is another essential factor to be taken into consideration.

\section{Conclusions}

This was the first detection of flumethrin resistance in Brazil. The T2134A mutation was not found in the populations studied.

\section{Acknowledgements}

We thank Dr. Armando Nari (DILAVE-MGAP, Uruguay) for providing us with the Mozo strain and USD-ARS for providing larval genomic DNA. This study was conducted with financial support from the National Council for Science and Technology Development (Conselho Nacional de Desenvolvimento Científico e Tecnológico, CNPq), project no. 578231/2008-5 (under an agreement between CNPq and MAPA-SDA).

\section{References}

Andreotti R, Guerrero FD, Soares MA, Barros JC, Miller RJ, Léon AP. Acaricide resistance of Rhipicephalus (Boophilus) microplus in State of Mato Grosso do Sul, Brazil. Rev Bras Parasitol Vet 2011; 20(2): $127-$ 133. PMid:21722487. http://dx.doi.org/10.1590/S198429612011000200007

Campos Jr DA, Oliveira PR. Avaliação in vitro da eficácia de acaricidas sobre Boophilus microplus (Canestrini, 1887) (Acari: Ixodidae) de bovinos no município de Ilhéus, Bahia, Brasil. Cienc Rural 2005; 35(6): 13861392. http://dx.doi.org/10.1590/S0103-84782005000600025

Conway GR, Comins HN. Resistance to pesticides. 2. Lessons in strategy from mathematical models. Span 1979; 22(2): 53-55.

Domingues LN, Brasil BSAF, Bello ACPP, Cunha AP, Barros ATM, Leite RC, et al. Survey of pyrethroid and organophosphate resistance in Brazilian field populations of Rhipicephalus (Boophilus) microplus: detection of C190a mutation in domain II of the para-type sodium channel gene. Vet Parasitol 2012; 189(2-4): 327-332. PMid:22647463. http://dx.doi.org/10.1016/j.vetpar.2012.04.031 
Farias NA, Ruas JL, Santos TRB. Análise da eficácia de acaricidas sobre o carrapato Boophilus microplus, durante a última década, na região sul do Rio Grande do Sul. Cienc Rural 2008; 38(6): 1700-1704. http://dx.doi. org/10.1590/S0103-84782008000600032

Fernandes FF. Efeitos toxicológicos e resistência a piretróides em Boophilus microplus de Goiás. Arq Bras Med Vet Zootec 2001; 53(5): 538-543. http:// dx.doi.org/10.1590/S0102-09352001000500004

Food and Agriculture Organization - FAO. Guidelines resistance management and integrated parasite control in ruminants. Roma; 2004. 77 p.

Furlong J, Martins JR, Prata MCA. O carrapato dos bovinos e a resistência: temos o que comemorar? A Hora Veterinária 2007; 27(159): 1-7.

Gomes A, Koller WW, Barros ATM. Suscetibilidade de Rhipicephalus (Boophilus) microplus a carrapaticidas em Mato Grosso do Sul, Brasil. Cienc Rural 2011; 41(8): 1447-1452. http://dx.doi.org/10.1590/S010384782011005000105

Guerrero FD, Davey RB, Miller RJ. Use of an allele-specific polymerase chain reaction assay to genotype pyrethroid resistant strains of Boophilus microplus (Acari: Ixodidae). J Med Entomol 2001; 38(1): 44-50. PMid:11268690. http://dx.doi.org/10.1603/0022-2585-38.1.44

He H, Chen AC, Davey RB, Ivie GW, George JE. Characterization and molecular cloning of glutathione $S$-transferase gene from the tick, Boophilus microplus (Acari: Ixodidae). Insect Biochem Mol Biol 1999; 29(8): 737-743. http://dx.doi.org/10.1016/S09651748(99)00056-9

Jonsson NN, Miller RJ, Robertson JL. Critical evaluation of the modified-adult immersion test with discriminating dose bioassay for Boophilus microplus using American and Australian isolates. Vet Parasitol 2007; 146(3-4): 307-315. PMid:17433549. http://dx.doi. org/10.1016/j.vetpar.2007.02.031

Jonsson NN, Cutullè C, Corley SW, Seddon JM. Identification of a mutation in the para-sodium channel gene of the cattle tick Rhipicephalus microplus associated with resistance to flumethrin but not to cypermethrin. Int J Parasitol 2010; 40(14): 1659-1664. PMid:20708620. http://dx.doi.org/10.1016/j.ijpara.2010.07.006

Leite RC. Boophilus microplus (Canestrini, 1887) susceptibilidade: uso atual e retrospectivo de carrapaticidas em propriedades das regióes fisiogeográficas da Baixada do Grande Rio e Rio de Janeiro, uma abordagem epidemiológica [Dissertação]. Rio de Janeiro: Universidade Federal Rural do Rio de Janeiro; 1988.

LeOra Software. Polo plus probit and logit analysis: user's guide. Berkeley, CA, USA; 2004.36 p.
Lovis L, Guerrero FD, Miller RJ, Bodine DM, Betschart B, Sager H. Distribution patterns of three sodium channel mutations associated with pyrethroid resistance in Rhipicephalus (Boophilus) microplus populations from North and South America, South Africa and Australia. Int $J$ Parasitol 2012; 2: 216-224.

Mendes MC, Pereira JR, Prado AP. Sensitivity of Boophilus microplus (Acari: Ixodidae) to pyrethroids and organophosphate in farms in the Vale do Paraíba region, São Paulo, Brazil. Arq Inst Biol 2007; 74(2): 81-85.

Morgan JAT, Corley SW, Jackson LA, Lew-Tabor AE, Moolhuijzen PM, Jonsson NN. Identification of a mutation in the para-sodium channel gene of the cattle tick Rhipicephalus (Boophilus) microplus associated with resistance to synthetic pyrethroid acaricides. Int $J$ Parasitol 2009; 39(7): 775-779. PMid:19367831. http://dx.doi. org/10.1016/j.ijpara.2008.12.006

Nolan J. Acaricide resistance in single and multi-host tick and strategies for control. Parassitologia 1990; 32(1): 145-153. PMid:2284128.

Nolan J, Wilson JT, Green PE, Bird PE. Synthetic pyrethroid resistance in field samples in the cattle tick (Boophilus microplus). Aust Vet J 1989; 66(6): 179-182. PMid:2775054. http://dx.doi. org/10.1111/j.1751-0813.1989.tb09796.x

Rosario-Cruz R, Guerrero FD, Miller RJ, Rodriguez-Vivas RI, Domínguez-García DI, Cornel AJ, et al. Roles played by esterase activity and by a sodium channel mutation involved in pyrethroid resistance in populations of Boophilus microplus (Acari: Ixodidae) collected from Yucatán, Mexico. JMed Entomol 2005; 42(6): 1020-1025. http://dx.doi. org/10.1603/0022-2585(2005)042[1020:RPBEAA]2.0.CO;2

Rosario-Cruz R, Guerrero FD, Miller RJ, Rodriguez-Vivas RI, Tijerina M, Dominguez-Garcia DI, et al. Molecular survey of pyrethroid resistance mechanisms in Mexican field populations of Rhipicephalus (Boophilus) microplus. Parasitol Res 2009; 105(4): 1145-1153. PMid:19565267 PMCid:PMC2729983. http://dx.doi.org/10.1007/s00436-009-1539-1

Soderlund DM, Knipple DC. The molecular biology of knockdown resistance to pyrethroid insecticides. Insect Biochem Mol Biol 2003; 33(6): 563-577. http://dx.doi.org/10.1016/S09651748(03)00023-7

Souza AP, Sartor AA, Bellato V, Perussolo S. Eficácia de carrapaticidas em rebanhos de bovinos leiteiros de municípios da região Centro-Sul do Paraná. Revta Ciênc Agrovet 2003; 2: 245-250.

Sutherst RW, Comins HN. The management of acaricide resistance in the cattle tick, Boophilus microplus (Canestrini) (Acari: Ixodidae), in Australia. Bull Entomol Res 1979; 69(3): 519-537. http://dx.doi. org/10.1017/S0007485300019015 